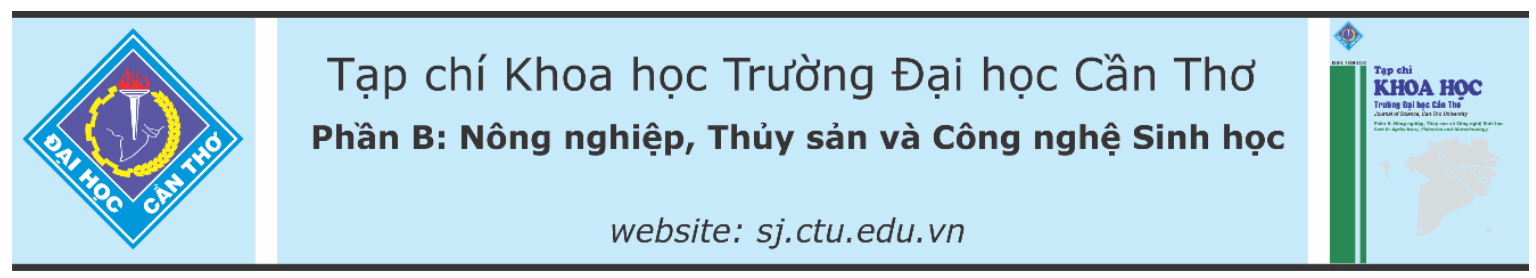

DOI:10.22144/ctu.jvn.2021.156

\title{
HOÀN THIỆN QUY TRÌNH TÁI SINH in vitro CHO GIỐNG LÚA NÀNG THOOM CHỌ ĐÀO
}

\author{
Nguyễn Văn Mạnh ${ }^{1}$, Đỗ Tiến Phát ${ }^{2}$, Trần In Đô ${ }^{1}$ và Huỳnh Kỳ̀ ${ }^{3 *}$ \\ ${ }^{1}$ Học viên cao học, Khoa Nông nghiệp, Trường Đại học Cần Tho \\ ${ }^{2}$ Viện Công nghệ Sinh học Việt Nam, Viện Hàn Lâm Khoa học và Công nghệ Việt Nam \\ ${ }^{3}$ Bộ môn Di truyền và Chọn giống Cây trồng, Khoa Nông nghiệp, Truờng Đại học Cần Tho \\ *Người chịu trách nhiệm về bài viết: Huỳnh Kỳ (email: hky@ctu.edu.vn)
}

\section{Thông tin chung:}

Ngày nhận bài: 21/03/2021

Ngày nhận bài sưa: 19/05/2021

Ngày duyệt đăng: 29/10/2021

\section{Title:}

The effectiveness method for regeneration in rice tissue culture of Nang Thom Cho Dao variety

\section{Tù khóa:}

Mô sẹo, Nàng Thơm Chọ Đào, phôi vô tính, tái sinh

\section{Keywords:}

Callus, Nang Thom Cho Dao, regeneration, somatic embryogenesis

\section{ABSTRACT}

In plant breeding, transgenic is one of the most effective approaches because of the introduction of the target gene directly into the varieties. This approach needs to be through a complete tissue culture system. One of the most problems of tissue culture in indica rice varieties is the conversion of callus into somatic embryogenesis and regeneration at very low rate. Therefore, this study is aimed to develop indica rice tissue culture with highly somatic embryogenesis rate and the effectiveness of the regeneration process for Nang Thom Cho Dao as well as rice varieties in the Mekong Delta. The result showed that N6D $(N 6+2,4 D)$ medium was suitable for callus induction (95-97\%), while MS+NAA+kinetin and $M S+B$ medium were used to induce $31.01 \%$ of somatic embryogenesis and regeneration, respectively. The results showed that the regeneration rate is still low, about $30.71 \%$ of the total induced callus. This result may be applicable for indica rice transgenic approach in the future.

\section{TÓM TẮT}

Trong công tác chọn tạo giống cây trồng, chuyển gene là một trong nhũng cách tiếp cận hiệu quả nhất vì đura trực tiếp gene muc tiêu vào giống cây nghiên cúu. Cách tiếp cận này cần phải thông qua hệ thống nuôi cẩy mô hoàn thiện. Một trong nhũng trở ngại lớn nhất của nuôi cấy mô ở các giống lúa thuộc nhóm indica là quá trình chuyển hóa các mô sẹo thành phôi vô tính và có tỷ lẹ tái sinh rất thấp. Chính vì vậy, nghiên cứu được tiến hành nhằm xây dụng và đánh giá hiệu quả quy trình tái sinh cho giống lúa Nàng Thom Chọ Đào (NTCD) cũng nhu mở rộng úng dụng cho các giống lúa khác ở vùng Đồng bằng sông Cưu Long. Trong nghiên cưu này, khả năng tạo mô sẹo trên môi truờng N6D $(N 6+2,4 D)$ với giống NTCD đạt hiệu quả tù 95 tới 97\%. Môi truờng phù hơp với giai đoạn phát sinh phôi soma và tái sinh chồi lần luoợt là $M S+N A A+$ kinetin và $M S+B$, với tỷ lẹ tạo chồi đạt 31,01\%. Tỷ lệ tạo cây hoàn chinh đạt 30,71\%, cây tái sinh được chuyển thành công ra trồng và chăm sóc trong điều kiện vuờn uoom. Kết quả này là co sở cho các nghiên cưu tiếp theo nhằm hoàn thiện quy trình tái sinh và ưng dụng trong việc chuyển gene vào giống lúa NTCD. 


\section{1. ĐẶT VẤN ĐỀ}

Sản lượng lương thực cung cấp luôn có nhu cầu rất cao do tốc độ tăng dân số và đô thị hóa nhanh, chính vì vậy áp lực chọn tạo giống lúa cung cấp đủ sản lượng và dinh dưỡng cũng như tăng cường khả năng chống chịu stress sinh học và phi sinh học là cấp thiết. Với những nhu cầu trên, phương pháp nuôi cấy mô cùng với chuyển gene là cách tiếp cận tốt nhất bằng cách đưa gene mục tiêu vào giống muốn cải thiện thông qua nhiều phương cách khác nhau. Theo ước tính có khoảng $80 \%$ giống lúa hiện đang được canh tác trên thế giới thuộc loài phụ indica. Vì vậy, việc chuyển các gene mang đặc tính nông học mong muốn vào giống lúa này là một trong những chiến lược cần được quan tâm (Tara et al., 2017). Tuy nhiên, các giống lúa thuộc nhóm indica thường có hiệu quả tái sinh thấp (Chu \& Croughan, 1990; Thao et al., 2021; Zuraida et al., 2010), điều này đã gây trở ngại cho việc ứng dụng phương pháp chuyển gene trong cải tạo các giống lúa indica quan tâm. Vì vậy, việc xây dựng quy trình nuôi cấy mô phù hợp, hiệu quả cho các giống lúa thuộc nhóm indica là rất cần thiết.

Trong quá trình nuôi cấy mô, việc kích thích chuyển hóa từ mô sẹo thành phôi vô tính (somatic embryogenesis) là một trong những bước quan trọng quyết định đến sự thành công của quy trình nuôi cấy mô. Ở cây lúa, giai đoạn chuyển từ mô sẹo sang phôi vô tính được thực hiện ở nhiều loại nguyên liệu khác nhau như từ phôi hạt chín (Wani et al., 2011), phôi non hay mô lá (Hiei \& Komari, 2008; Ramesh et al., 2009), rễ (Abe \& Futsuhara, 1985; Hoque \& Mansfield, 2004), cụm hoa lúa (Ling et al., 1983)... Kể từ năm 1995, kỹ thuật nuôi cấy mô phát triển mạnh mẽ trên nhiều loài cây khác nhau, cụ thể đã có hơn 200 loài cây trồng được nghiên cứu và đã được công bố về quy trình chuyển hóa thành công phôi vô tính (Raemarkers et al., 1995) và tiếp tục phát triển cho những năm gần đây. Hầu hết các quy trình chuyển hóa phôi vô tính thường không trực tiếp từ mô mà phải qua giai đoạn từ mô sẹo. Tuy nhiên, kết quả nghiên cứu cho thấy tỷ lệ chuyển hóa thành công phôi vô tính trực tiếp từ 25 quy trình nuôi cấy mô giống lúa indica chỉ thành công $30 \%$, trong khi chuyển hóa không trực tiếp chỉ thành công có $8 \%$ (Tara et al., 2017).

Có rất nhiều yếu tố ảnh hưởng đến sự phát triển từ tế bào phôi thành phôi vô tính trong đó bao gồm cả thành phần và nồng độ chất điều hòa sinh trưởng, loại và giai đoạn của mô làm vật liệu nuôi cấy, môi trường nuôi cấy, kiểu gene và than hoạt tính hay các hợp chất sinh hóa ảnh hưởng lên quá trình hình thành phôi vô tính và dẫn đến tiến trình tái sinh cây (Deo et al., 2010). Trong nghiên cứu này, quy trình cho việc tạo phôi vô tính và tái sinh tạo cây hoàn chỉnh ở giống lúa Nàng Thơm Chợ Đào thuộc nhóm indica được xây dựng, kết quả này là cơ sở cho các nghiên cứu chuyển gene vào giống lúa này trong tương lai.

\section{VẬT LIỆU VÀ PHƯƠNG PHÁP NGHHẾN CÚU}

\subsection{Vật liệu nghiên cứu}

Giống lúa Nàng Thơm Chợ Đào có nguồn gốc từ xã Mỹ Lệ, huyện Cần Đước, tỉnh Long An. Gần đây được cán bộ Khoa Nông nghiệp thu thập và hiện đang tồn trữ ở Ngân hàng giống Khoa Nông nghiệp - Trường Đại học Cần Thơ.

\subsection{Phương pháp nghiên cứu}

\subsubsection{Xây dựng quy trình tái sinh}

Các bước của quy trình tái sinh được thực hiện dựa trên công bố của Nishimura et al. (2006) với thành phần môi trường (Bảng 1 ) và các bước tóm tắt như sau:

Khư trùng và gieo hạt: Hạt lúa được bóc vỏ trấu và được khử trùng bằng ethanol $\left(\mathrm{C}_{2} \mathrm{H}_{5} \mathrm{OH}\right) 70 \%$ trong 1 phút, sau đó lắc 45 phút trong sodium hypochlorite $(\mathrm{NaClO}) 60 \%$ có thêm 1 - 2 giọt Tween 20. Rửa lại bằng nước thanh trùng khoảng $5-6$ lần. Thấm khô hạt gạo và gieo trên môi trường tạo mô sẹo (N6D) trong điều kiện tối.

Nhân mô sẹo: Sau 2 tuần trên môi trường, N6D trong điều kiện tối và nhiệt độ từ $25-28^{\circ} \mathrm{C}$, mô sẹo phát sinh từ phôi sẽ tách ra và cấy chuyển sang môi trường N6D.

Cảm úng tạo phôi soma: Mô sẹo trên môi trường N6D được chuyển sang môi trường MSNK và nuôi trong điều kiện tối ở $28^{\circ} \mathrm{C}$ trong 15 - 20 ngày.

Giai đoạn tái sinh: Sau 15 - 20 ngày trên môi trường MSNK, những mô sẹo rắn chắc được lựa chọn và cấy sang môi trường tái sinh $(\mathrm{MS}+\mathrm{B})$ và nuồi cấy trong phòng nuôi với thời gian chiếu sáng 12 giờ sáng $/ 12$ giờ tối, nhiệt độ phòng $26-28^{\circ} \mathrm{C}$.

Tạo rễ và cây hoàn chỉnh: Sau 2 - 3 tuần trên môi trường tái sinh, chồi mới phát triển đạt khoảng $2-3 \mathrm{~cm}$ được chuyển sang môi trường tạo rễ (MS). Cây lúa hoàn chỉnh với bộ rễ tốt được chuyển ra chăm sóc trong nhà lưới. 
Bảng 1. Thành phần của các loại môi trường được sử dụng trong nghiên cứu (Nishimura et al., 2006)

\begin{tabular}{|c|c|c|}
\hline Giai doạn & Môi trường & Thành phần \\
\hline Tạo mô sẹo & N6D & $\begin{array}{l}\mathrm{N} 6 \text { (Chu et al., } 1975)+2 \mathrm{mg} / \mathrm{L} \text { 2,4-D + } 100 \mathrm{mg} / \mathrm{L} \text { myo-inositol + } 300 \mathrm{mg} / \mathrm{L} \\
\text { casamino acid }+2,878 \mathrm{~g} / \mathrm{L} \text { L-proline }+30 \mathrm{~g} / \mathrm{L} \text { sucrose }+7 \mathrm{~g} / \mathrm{L} \text { agar, } \mathrm{pH} 5,8\end{array}$ \\
\hline $\begin{array}{l}\text { Tiền tái } \\
\text { sinh }\end{array}$ & MSNK & $\begin{array}{l}\text { MS (Murashige \& Skoog, 1962) }+0.2 \mathrm{mg} / \mathrm{L} \text { NAA }+2 \mathrm{mg} / \mathrm{L} \text { kinetin }+100 \\
\mathrm{mg} / \mathrm{L} \text { myo-inositol }+2 \mathrm{~g} / \mathrm{L} \text { casamino acid }+30 \mathrm{~g} / \mathrm{L} \text { sucrose }+30 \mathrm{~g} / \mathrm{L} \\
\text { sorbitol + } 7 \mathrm{~g} / \mathrm{L} \text { agar, pH 5,8 }\end{array}$ \\
\hline Tái sinh & $\mathrm{MS}+\mathrm{B}$ & $\mathrm{MS}+1 \mathrm{mg} / \mathrm{L} \mathrm{BAP}+30 \mathrm{~g} / \mathrm{L}$ sucrose $+7 \mathrm{~g} / \mathrm{L}$ agar, $\mathrm{pH} 5,8$ \\
\hline Ra rễ & MS & $\mathrm{MS}+30 \mathrm{~g} / \mathrm{L}$ sucrose $+7 \mathrm{~g} / \mathrm{L}$ agar, $\mathrm{pH} 5,8$ \\
\hline
\end{tabular}

\subsubsection{Phuoong pháp phân tích số liệu}

Thí nghiệm được bố trí hoàn toàn ngẫu nhiên với 3 lần lặp lại. Mỗi lần lặp lại có 40 đĩa petri và mỗi đĩa có 10 - 12 mẫu. Trước khi cấy chuyển sang môi trường mới, sẽ đếm số mẫu chết và số mẫu cấy chuyển sang môi trường mới. Số liệu được thu thập và phân tích bằng phần mềm Excel 2013.

\section{KẾT QUẢ VÀ THẢO LUÂN}

\subsection{Giai đoạn tạo mô sẹo}

Chất lượng mô sẹo là yếu tố rất quan trọng ảnh hưởng trực tiếp tới khả năng tái sinh và hiệu quả chuyển gene sau này. Hình 1 cho thấy khả năng tạo mô sẹo từ giai đoạn gieo hạt cho đến 14 ngày sau khi gieo trên môi trường $\mathrm{N} 6 \mathrm{D}$, mô sẹo phát sinh từ phôi có kích thước tương đối lớn $(4-5 \mathrm{~mm})$ thành khối chai cứng, tuy nhiên có 1 số mô sẹo bị mềm nhũn do hấp thu nhiều nước. Kết quả ghi nhận trên
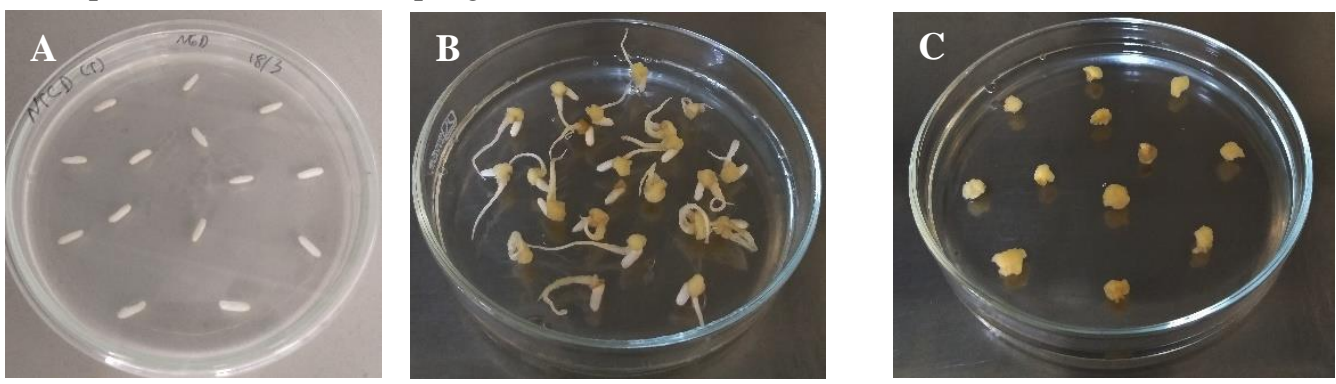

Hình 1. Phát sinh mô sẹo từ phôi hạt

(Ghi chú: A: bắt đầu gieo hạt; B: sau 2 tuần gieo hạt; C: sau khi cắt mô sẹo ra khỏi hạt)

\subsection{Giai đoạn cảm úng tạo phôi soma}

Giai đoạn tiền tái sinh được nuôi cấy trong điều kiện tối nhằm tăng cường khả năng phân hóa của tế bào, tạo mô sẹo trưởng thành. Kết quả sau 3 lần thí nghiệm cho thấy các mô sẹo phát triển rất tốt trên môi trường MSNK. Cụ thể, sau 15 - 20 ngày, 99,05 môi trường N6D, tỷ lệ tạo mô sẹo từ phôi hạt chín đạt từ $95 \%$ đến $97 \%$. Kết quả này tương đương so với nghiên cứu của Rahman et al. (2010) đã công bố trên giống MR232, một loài phụ indica (trên môi trường tối ưu M3 tỷ lệ tạo mô sẹo đạt 91-97\%). Ngoài ra, ở nghiên cứu của Phan Thị Hương và ctv. (2014), khả năng cảm ứng mô sẹo của các giống lúa khác nhau có độ biến động lớn và phụ thuộc vào môi trường nuôi cấy. Cụ thể, tỷ lệ tạo mô sẹo của các giống BM9630, J02, NV1, NV3 và Hương cốm lần lượt là: $69 \%, 98 \%, 92 \%, 75 \%$ và $97 \%$ khi được nuôi cấy trên môi trường N2. Trong khi đó, giống NV2 và $\mathrm{BC} 15$ có tỷ lệ hạt tạo mô sẹo cao nhất trên môi trường $\mathrm{M} 2(83 \%$ và $72 \%)$. Qua đó nhận thấy môi trường $\mathrm{N} 6 \mathrm{D}$ được sử dụng trong nghiên cứu này cho giống lúa Nàng Thơm Chợ Đào mang lại hiệu quả tạo mô sẹo tốt so với các công bố trước đây với giống lúa khác.

Bảng 2. Kết quả đánh giá hiệu quả của quy trình giai đoạn tiền tái sinh thông qua mô sẹo

\begin{tabular}{crrrr}
\hline Lần thí nghiệm & Số mẫu & Tỷ lệ nhiễm (\%) & Tỷ lệ chết (\%) & Tỷ lệ sống (\%) \\
\hline Lần 1 & 210 & 0 & 0,48 & 99,52 \\
Lần 2 & 215 & 0 & 0,93 & 99,07 \\
Lần 3 & 210 & 0 & 1,43 & 98,57 \\
\hline Trung bình & & 0 & 0,95 & 99,05 \\
\hline
\end{tabular}



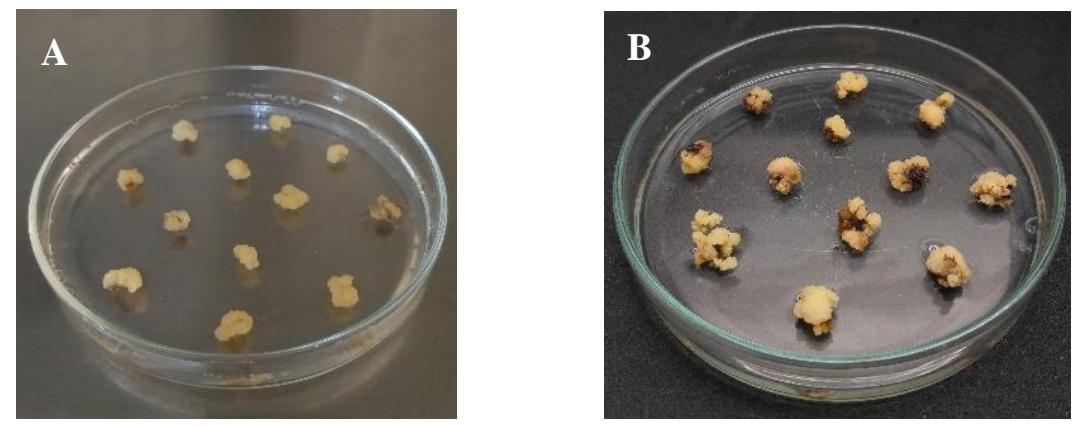

Hình 2. Mô sẹo phát triển trên môi trường tiền tái sinh sau 9 ngày nuôi cấy. (A: 0 ngày trên môi trường cảm ứng tạo phôi soma; $B$ : 9 ngày trên môi trường cảm ứng tạo phôi soma)

\subsection{Giai đoạn tái sinh và tạo cây hoàn chỉnh}

Kết quả của giai đoạn tái sinh sau 1 tuần trên môi trường $\mathrm{MS}+\mathrm{B}$ có $31,01 \%$ mô sẹo dạng tơi xốp, xuất hiện các chồi xanh có kích thước nhỏ, sau đó các mô sẹo tiếp tục phát triển thành cây con sau hai tuần nuôi cấy. Còn lại các mô sẹo bị khô, teo lại và bắt đầu chết. Từ những cụm mô sẹo xuất hiện chồi cây con tiếp tục cấy chuyển sang môi trường MS ra rễ, sau 2 tuần nhận thấy $100 \%$ đều phát triển thành cây hoàn chỉnh. Như vậy, quy trình tái sinh cây từ mô sẹo phôi hóa đạt tỷ lệ khoảng $30,71 \%$ trên tổng số mẫu ban đầu đã làm (Bảng 3 và Bảng 4). So với một số nghiên cứu trước đây, tỷ lệ tái sinh của các giống lúa indica khoảng 30\% đối với phương pháp tạo phôi vô tính trực tiếp và chỉ có $8 \%$ đối với gián tiểp thông qua mô sẹo (Tara et al., 2017). Như vậy, so với các quy trình trước, quy trình này cho thấy hiệu quả và phù hợp với giống lúa indica, cụ thể là giống lúa Nàng Thơm Chợ Đào.

\section{Bảng 3. Kết quả đánh giá hiệu quả của quy trình giai đoạn tái sinh}

\begin{tabular}{crrrr}
\hline Lần thí nghiệm & Số mẫu & Tỷ lệ nhiễm & Tỷ lệ chết (\%) & Tỷ lệ tạo chồi (\%) \\
\hline Lần 1 & 209 & 0 & 67,90 & 32,10 \\
Lần 2 & 213 & 0 & 68,54 & 31,46 \\
Lần 3 & 207 & 0 & 70,53 & 29,47 \\
\hline Trung bình & & 0 & 68,99 & 31,01 \\
\hline
\end{tabular}

Bảng 4. Kết quả tái sinh của quy trình

\begin{tabular}{crrr}
\hline Lần thí nghiệm & Tổng số mẫu ban đầu & Tổng số mẫu tái sinh & Tỷ lệ tái sinh (\%) \\
\hline Lần 1 & 210 & 67 & 31,90 \\
Lần 2 & 215 & 67 & 31,16 \\
Lần 3 & 210 & 61 & 29,05 \\
\hline Trung bình & & & 30,71 \\
\hline
\end{tabular}
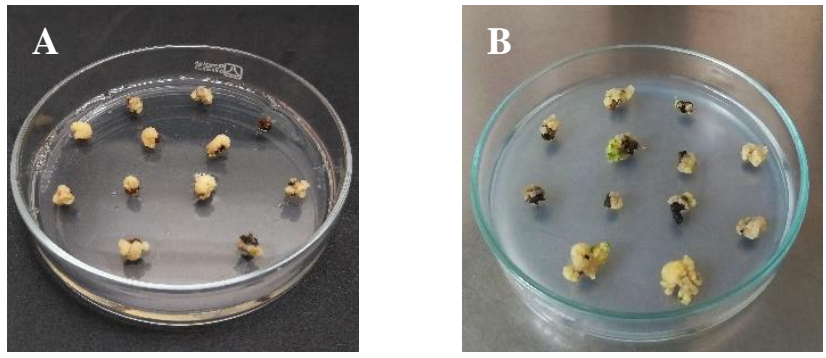

Hình 3. Mô sẹo phát triển trên môi trường tái sinh sau 14 ngày nuôi cấy

(Ghi chú: A: 0 ngày trên môi truòng tái sinh; B: 14 ngày trên môi truò̀ng tái sinh) 


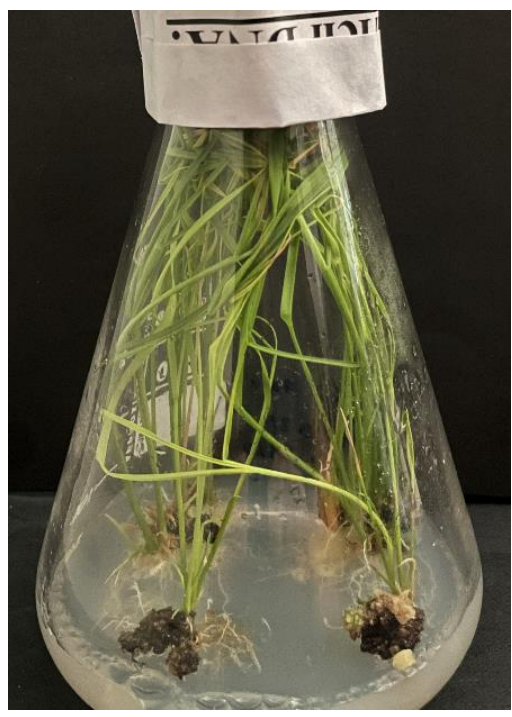

Hình 4. Phôi vô tính phát triển thành cây hoàn chỉnh trên môi trường MS

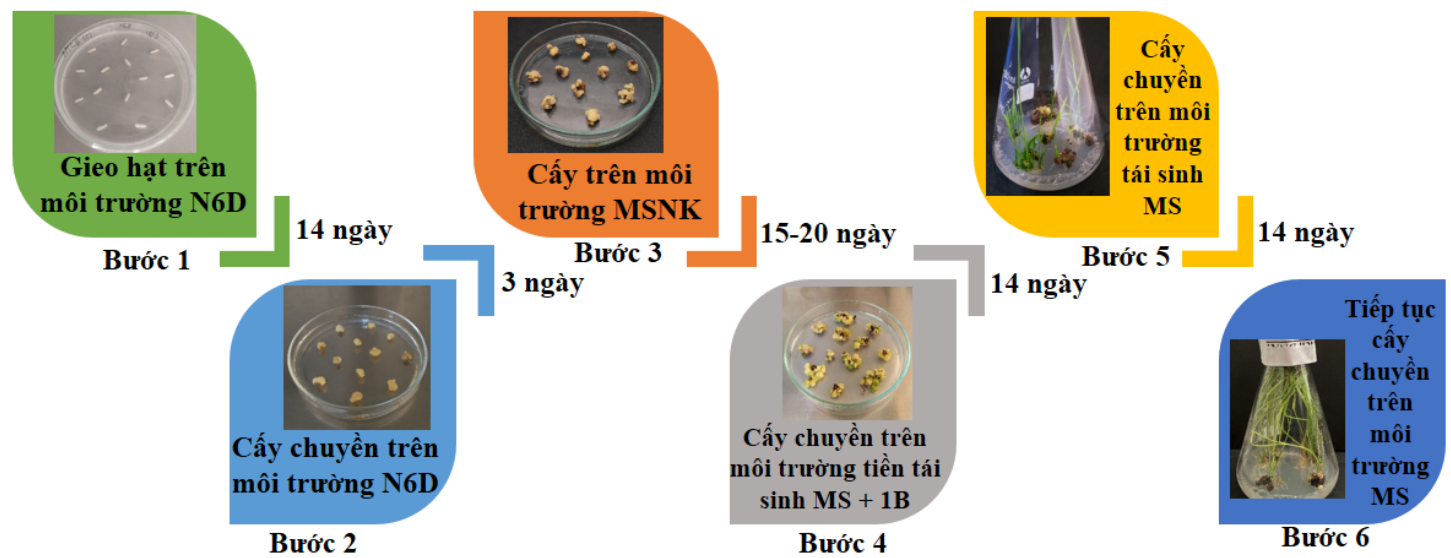

Hình 5. Quy trình tái sinh cây in vitro của Giống lúa Nàng Thơm Chợ Đào

\section{KẾT LUẬN VÀ ĐỀ XUẤT}

\subsection{Kết luận}

Nghiên cứu đã cho thấy bước đầu xây dựng thành công quy trình tái sinh thông qua phôi vô tính ở giống lúa Nàng Thơm Chợ Đào. Trong đó, mô sẹo được hình thành và phát triển tốt nhất trên môi trường N6D (N6+2,4D) với tỷ lệ đạt trên $95 \%$ từ phôi hạt. Tỷ lệ tạo phôi vô tính và tái sinh đạt $31,01 \%$ sau 2 tuần trên môi trường $\mathrm{MS}+1 \mathrm{~B}$ (MS+BAP). Tỷ lệ tái sinh cây hoàn chỉnh của quy trình đạt $30,71 \%$.

\section{2. Đề xuất}

Tiếp tục hoàn thiện và áp dụng quy trình nuôi cây mô này trong công tác chuyển gene mục tiêu vào giống lúa NTCĐ cũng như các giống lúa khác thuộc nhóm indica.

\section{LỜI CẢM TẠ}

Nghiên cứu được tài trợ bởi dự án Nâng cấp Trường Đại học Cần Thơ VN14-P6 (vốn vay ODA từ chính phủ Nhật Bản). Chân thành cám ơn Thầy Võ Công Thành đã chia sẻ nguồn gene.

\section{TÀI LIỆU THAM KHẢO}

Abe, T. \& Futsuhara, Y. (1985). Efficient plant regeneration by somatic embryiogenesis from root callus tissuse of rice in rice (Oryza sativa $\mathrm{L}$.). Journal of Plant Physiology, 121(2), 111-118.

Chu, C.C., Wang, C.C., Sun, C.S., Msu, C., Yin, K.C., Chu, C.Y., \& Bi, F.Y. (1975). Establishment of an efficient medium for anther cultures of rice 
through comparative experiments on nitrogen sources. Sci China Math, 18(5), 659-668.

Chu, Q.R., \& Criughan, T.P. (1990). Genetics of plant regeneration in immature panicle culture of rice. Crop Sciences, 30, 1194-1390.

Deo, P.C., Tyagi, A.P., Taylor, M., Harding, R. \& Becker, D. (2010). Factors affecting somatic embryogenesis and transformation in modern plant breeding. The South Pacific journal Nat. and Appl. Sci, 28, 27-40.

Hiei, Y. \& Komari, T. (2008). Agrobacteriummediated transformation of rice usinf immature embryos or calli induced from mature seed. Nature protocols, 3(5), 824-834.

Hoque, M.E. \& Mansfield, J.W. (2004). Effect of genotype and explant age on callus induction and subsequent plant regeneration from root-derived callus of indica rice genotypes. Plant Cell, Tissue Organ Culture, 78, 217-223.

Ling, D.H., Chen, W.Y., Chen, M.F. \& Ma, Z.R. (1983). Somatic embryogenesis and plant regeneration in interspecific hydrid of Oryza. Plant Cell report, 2, 169-171.

Murashige, T., \& Skoog, F. (1962). A revised medium for rapid growth and bioassays with tobacco tissue cultures. Physiol Plant, 15, 473-497.

Nishimura, A., Aichi, I., \& Matsuoka, M. (2006). A protocol for Agrobacterium-mediated transformation in rice. Nature protocols, 1(6), 2796-802.

Phan Thị Hương, Nguyễn Thị Phương Thảo, Nguyễn Thị Thùy Linh, Nguyễn Tràng Hiếu \& Ninh Thị
Thảo. (2014). Xây dựng hệ thống tái sinh in vitro trên cây lúa. Tạp chí Khoa học và Phát triển, 12(8), 1249-1257.

Raemarkers, C.J., Jacobsen, E., Visser, R.G.F. (1995). Secondary somatic embryogenesis and application in plant breeding. Euphytica, 81, 93-107.

Rahman, Z.A. (2010). Production of transgenic Indica rice (Oryza sativa L.) Cv. MR 81 via particle bombardment system. Emirates Journal of Food and Agriculture, 22(5), 353-366.

Ramesh, M., Murugiah, V. \& Gupta, A.K. (2009). Efficient in vitro plant regeneration via leaf base segment of indica rice (Oryza sativa L.). Indian journal of Experiment Biology, 47, 68-74.

Tara, N., Sindhu, M. \& Kaur, P. (2017). Review: Problem and Progress in Indica Rice Tissue Cuture Techniques. Annals of Biology, 33, 191-198.

Thao, B.P., Linh, N.T., Manh, N.V., Linh, L.K., Ha, C.H., Phat, D.T., \& Ngoc. P.B. (2021).

Optimization of Agrobacterium - mediated transformation procedure for an indica rice variety - Khangdan 18. Journal of Biotechnology, 19(2). (accepted)

Wani, S.H., Sanghera, G.S. \& Gosal, S.S. 2011. An efficient and reproducible method for regeneration of whole plants from mature seeds of a high yielding indica rice (Oryza sativa L.) var PAU 201. New Biotechnology, 28, 418-422.

Zuraida, A.R., Suri, R., Zailiha, W.S., \& Sreeamanan, S. (2010). Regeneration of Malaysia indica rice (Oryza sativa L.) variety MR 323 via optimized somatic embryogenesis system. Journal Phytology, 2(3), 30-38. 